\title{
Research on Industrialization Platform of Design Achievements of Design Majors in Colleges and Universities*
}

\author{
Dehui Ye \\ School of Art \& Design \\ Guilin University of Electronic Technology \\ Guilin, China 541004 \\ Yuanyuan Tan \\ School of Art \& Design \\ Guilin University of Electronic Technology \\ Guilin, China 541004
}

\author{
Xiongyan Yang \\ School of Art \& Design \\ Guilin University of Electronic Technology \\ Guilin, China 541004 \\ Shana Wang \\ School of Art \& Design \\ Guilin University of Electronic Technology \\ Guilin, China 541004
}

\begin{abstract}
Design majors of colleges and universities in China have accumulated a large number of design achievements, but due to various reasons, the transformation rate of these achievements is extremely low. Through the construction of the industrialization platform of the design achievements of design majors in colleges and universities, we will integrate various industrialization modes by means of Internet technology, which can greatly enhance the efficiency and success rate of industrialization.
\end{abstract}

Keywords-design major; design achievements; industrialization platform

\section{INTRODUCTION}

Design is a practice-oriented discipline. With the aim of practical teaching, project teaching provides a possibility for the productization of design achievements while improving students' practical ability[1]. The design achievements of design majors in colleges and universities are the crystallization of intellectual work of college teachers and students, reflecting the level of school running. The industrialization of design achievements is conducive to enhancing students' creative enthusiasm and has certain practical significance for improving students' professional practice ability.

\section{The Status Quo of Design ACHIEVEMENTS OF DESIGN MAJORS IN COLLEGES AND UNIVERSITIES}

Design is a practice-oriented discipline. With the aim of practical teaching, project teaching provides a possibility for the productization of design achievements while improving

*[Fund program]: School-level Key Education Reform Project in Guilin University of Electronic Technology in 2016 (JGA201601), Class A Project of Teaching Reform Project Establishment in the Undergraduate of Higher Education in Guangxi in 2017 (2017JGA201), Degree and Postgraduate Teaching Reform Program in Guangxi in 2018 (JGY2018060)

Chinese Library Classification No.: J06 students' practical ability[1]. The design achievements of design majors in colleges and universities are the crystallization of intellectual work of college teachers and students, reflecting the level of school running. The existing teaching achievements of design majors in colleges and universities have the following two characteristics:

\section{A. Abundant Resources}

The design major in colleges and universities has very rich resources. For example, after years of schooling, the author's university has accumulated a large number of student course assignment, course design and graduation project. Among them, there are thousands of graduation designs, each of which is carefully designed by students and has unique originality. Although they have some defects, it does not affect the value of the achievements. These rich resources have laid the foundation for the transformation of achievements.

\section{B. Complex Types}

The types of design achievements are complex, which include product packaging design, plane design, environmental design and animation video apart from the regular product design. Different types need to choose different cooperation objects and adopt different cooperation methods. For example, product design is applied to the company's new product development, and plane design is widely used in advertising and promotion of products, so we need to treat them differently in the transformation process.

\section{Numerous Participants}

There are many existing design majors in colleges and universities. According to the enrollment information published by Ministry of Education, more than 1400 colleges and universities recruited art students in 2009, and $80 \%$ of them opened art design majors. Such enormous student groups 
have to complete different assignments and designs every year, reflecting the universality of the achievements.

\section{Achievements Are Not Valued}

Since most colleges and universities are not aware of the importance of these design achievements, even do not regard them as resources, and consider them as a burden, so they all deal with these achievements at will, or save them, or dispose them as garbage, resulting in heavy resource waste.

\section{INDUSTRIALIZATION OF DESIGN INNOVATION ACHIEVEMENTS}

Design majors in colleges and universities have a large number of design resources, and many students also participate in the course, but there are some problems in industrialization.

\section{A. Relatively Low Industrialization Rate}

The overall industrialization rate is low. According to the statistics of State Intellectual Property Bureau, there are more than 100,000 artistic creative design patent achievements per year, but the transformation rate of these patent achievements is less than $3 \%$, and most of the achievements have no chance to be industrialized[2]. However, enterprises have not realized the importance of these teaching achievements, and only a small part of the enterprises have applied for patents. Thus it can be seen that the overall industrialization rate of the achievements is very low.

\section{B. Unbalanced Industrialization Rate}

Due to the imbalance of economic development, the design majors of colleges and universities in the eastern region generally do better in design teaching and achievements industrialization. On the one hand, because of more contact with the market, the awareness of the active industrialization of the colleges and universities is better; on the other hand, local government enterprises provide a good environment and conditions for the industrialization of achievements, which facilitates the industrialization of design achievements. Relatively speaking, colleges and universities in the western region are relatively poor in this respect, and a large number of design resources have no way to be transformed, resulting in great waste.

\section{Lack of Integration of Industrialization Platform}

Although design majors of colleges and universities in China are adopting some different models to industrialize design achievements, the industrialization rate is relatively low in general. The most fundamental reason is the lack of an integrated industrialization platform, resulting in information asymmetry between enterprises and universities. In university, a large number of innovative results have been shelved, and they cannot find objects that can be transformed. In the enterprise, the development of new products requires all aspects of design, but they cannot find a design that can be adopted. Although enterprises can seek university cooperation by using some scattered models, such as purchasing patents and award-winning design works, the lack of integration in these methods has brought great trouble to enterprises.

\section{TREND AND DEVELOPMENT OF INDUSTRIALIZATION}

With the development of economy and improvement of technology, in recent years, the way of industrialization of innovative teaching achievements in colleges and universities is increasing and the pace of industrialization is accelerating.

\section{A. Industrialization Trends of Design Innovation Teaching Achievements}

Industrialization trends are mainly presented in the following aspects:

1) Diversified financing method: For the design achievements, to make it become industrialization, the biggest problem comes from the financing. Due to the lack of evaluation on anticipated achievement benefit, the banks will not easily lend money. However, with the development of Internet Finance, the financing methods have undergone great changes. China has various preferential financing policies for small and micro enterprises, and banks also have a variety of new financing platforms. Not only that, the design achievements also can finance through crowd funding platform.

2) Social platformization of achievements industrialization [3]: In the process of transforming the design achievements, due to the lack of understanding on the market, colleges and universities easily dare not transform the achievements. With the increasing popularity of social media, a large amount of information is shared, evaluated, discussed and communicated. New designs can obtain feedback through social platforms to determine whether there is an industrial prospects. Even it can achieve flattening of the achievement transformation through social media for financing and designed sales, and save costs, thereby improving transformation efficiency.

3) Internetization of achievements industrialization: With the development of the Internet, it provides a more convenient and fast channel for the industrialization of design achievements of colleges and universities. The information sharing mechanism of the Internet avoids the asymmetric information between universities and enterprises, thus establishing the bridge between demand and design, therefore, it make the transformation of design achievements become more direct and convenient, for example, a large number of teachers and students in design major of colleges become "Witkey", and the so-called Witkey refers to those who transform their wisdom, knowledge, ability, experience into actual income through the Internet. Therefore, in the new era, the achievements industrialization has achieved real Internetization.

\section{B. New Ways of Industrialization}

There have been some new ways to transform the achievements of innovative design, breaking the previous single way of relying on the connection between colleges and enterprises to carry out achievements industrialization: 
1) One-to-one connection of enterprise demand and teachers and students in design major: Due to the role of the Internet platform, it has brought a lot of convenience to the transformation of design achievements of universities and colleges. Now there are many websites with intermediary nature, which can be provided to enterprises and universities. Some are led by government departments, for example, Zhejiang Internet technology market which has large number of innovative design achievements of universities and colleges in Zhejiang; some have pure nature of business, such as Zhubajie network which provides with large design demands and also offers many design service, achieving the one-to-one connection of enterprise and designer.

2) Crowd funding model that directly faces customers [4]: Crowd funding adopts the characteristics of propagation of Internet and SNS to make small businesses, artists or individuals to show their ideas to the public, obtain people's attention and support, and then get the needed financial assistance. The rise of the crowd funding model has directly changed the existing design transformation model. In the traditional industrialization model, investors must have a good market insight, have their own financing channels, and then be familiar with the development process of products, know how to save the costs, better know how to market products. In the context of the product development model of the modern whole industry chain, through crowd funding, it not only can know the market, but also can directly raise funds and promote products, which makes the transformation of design achievements easier and accelerates the transformation of design achievements.

3) Online platform model that directly sells: Direct sales of design achievements are also common industrialization models. Some colleges have exhibition halls or shops that directly sell students' designs work. However, in the Internet age, they no longer rely on traditional sales models, but sell the work through the network. For example, they use Taobao to sell some individualization products with good innovation. By network sale, it can expand the market while saving on marketing costs.

\section{INDUSTRIALIZATION PLATFORM CONSTRUCTION}

There are a large number of design and innovation achievements in the design major of colleges and universities, but their industrialization rate is low, and lacks good channels and platforms. Therefore, it is urgent to establish a new industrialization platform for design achievements.

\section{A. Construction Thoughts of Industrialization Platform}

The Internet has revolutionary potential to transform social communication and collaboration models [5]. In the Internet era, combined with new technical means and thinking modes, it is necessary to integrate different industrialization models to form a new Internet industrialization platform. The detailed construction thoughts are shown in Fig.1:

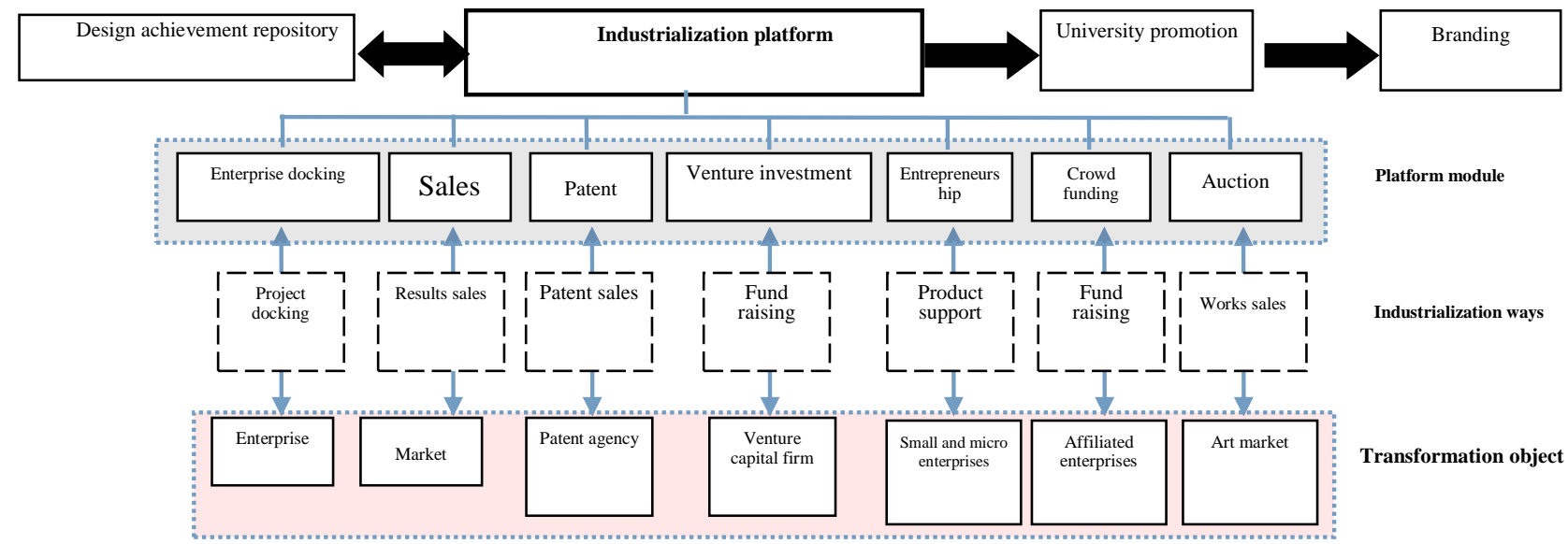

Fig. 1. Thoughts on the construction of industrialization platform for design achievements.

It can be seen from Diagram 1 that industrialization platform makes full use of the advantages of the Internet, connects the design achievement repository, promotes then with the help of universities, finally forms the branding of the industrialization platform, and obtains the recognition of enterprises and universities, so as to make them realize the value of industrialization, gather the popularity, and accelerate the transformation of design achievements. The industrialization platform has integrated the transformation modes of different designs, including seven modules, that is, enterprise docking, sales, patents, venture investment, entrepreneurship, crowd funding and auction, which provides many possibilities for the industrialization of design achievements.

\section{B. Characteristics of Industrialization Platform}

The industrialization platform of design achievements has the following characteristics:

1) Integralization: As an industrial platform, it is necessary to integrate the common ways of industrialization and change the original scattered and random chrematistics of industrialization. Only through integration can we gather resources and popularity for the industrialization platform, 
and gain recognition from both enterprises and universities. Meanwhile, only through integration can we meet the different needs of enterprises and provide services to teachers and students anytime and anywhere.

2) Internetization: The industrialization platform is built based on Internet, so it has obvious Internet characteristics, namely, equality, openness and high efficiency. Therefore, the platform is open to everyone. Whether a freshman in design major or an experienced postgraduate, and whether a large enterprise or a small and micro enterprise in China, they are all equal, and open to all the people. Moreover, the construction of the platform has greatly improved the efficiency.

3) Sharing: A large number of design resources in colleges and universities can be recognized by enterprises and markets only through the promotion of industrialization platforms. At the same time, the value of the design achievements will gradually be recognized only through sharing in the process of the industrialization of the design achievements, so the sharing characteristics of the industrialization platform is conducive to the embodiment of the value of design achievements.

4) Propagation: The industrial platform itself is a platform for propagation, and makes promotion by means of various means of propagation. For example, in the new mobile Internet era, the use of existing mobile media for propagation can bring more popularity and traffic to the industrialized platform, so as to realize the rapid spread of the industrialized platform.

\section{CONCLUSION}

With the use of Internet technology, we integrate the existing industrialization ways of different design achievements, establish the industrialization platform of design achievements, and carry out the spread and promotion of the platform, which can greatly improve the conversion efficiency of design results, gain recognition from enterprises and universities, and enhance the transformation rate of achievements.
[5] Zhao Fuzeng, Ding Xuewei. Mass Collaborative Innovation on the Internet Platform [J]. China Soft Science, 2009, (05): 63-72. 赵夫增,丁 雪伟. 基于互联网平台的大众协作创新研究 [J]. 中国软科 学,2009,(05):63-72.

\section{REFERENCES}

[1] Tang Jichuan. Analysis of Operational Mechanism of Productization of Design Achievements [J]. Beauty \& Times , 2015, (04): 114-117. 唐济 川. 设计成果产品化的运行机制分析[J]. 美与时代(上),2015,(04):114117.

[2] Cheng Zhili. A Research on Art Design Teaching and Features of Industrialization of Research Findings in Colleges and Universities [J]. Art Panorama, 2010, 11: 142-143. 程智力. 高校艺术设计教学和科研 成果产业化特征研究[J]. 美术大观,2010,11:142-143.

[3] Mou Enmin. On the Cross-border E-commerce on Social Platforms [J]. Guide To Business, 2016, (13): 108-109. 牟恩民. 浅谈社交平台跨界 电子商务[J]. 企业导报,2016,(13):108-109.

[4] Rong Xiaofeng, Liu Lin, Dong Chuan. Research on Internet Crowdfunding to Promote the Development of Small and Micro Technology-based Enterprise [J]. Friends of Accounting, 2016, (06):4043. 荣晓峰,刘琳, 董川. 互联网众筹融资促进科技型小微企业发展研 究[J]. 会计之友,2016,(06):40-43. 